\title{
The effect of cognitive absorption on marketing learning performance
}

\section{El efecto de la absorción cognitiva en los resultados de aprendizaje de marketing}

\author{
Miguel Guinaliu-Blasco, Blanca Hernández-Ortega and José L. Franco \\ Department of Marketing, University of Zaragoza, Zaragoza, Spain
}

\begin{abstract}
Purpose - The purpose of this paper is to analyse the individual's experience during the use of Pinterest in a marketing learning process. This experience is a fundamental starting point from which to develop marketing learning processes that flow naturally. Thus, it is necessary to examine the components that determine the individual's experience and to explore consequences such as collaborative learning and marketing learning performance.

Design/methodology/approach - To conceptualise the individual's experience, this study focuses on her/his state of cognitive absorption (CA) and establishes a second-order formative structure made up of five components: heightened enjoyment, curiosity, control, temporal dissociation and focused immersion. The model is estimated with partial least squares modelling, using SmartPLS 2.0 software.

Findings - The results confirm the significant weights of the components, with the exception of focused immersion, and support the influence of overall CA on the proposed outcomes. They also confirm that collaborative learning exerts a positive influence on the individual's performance.

Originality/value - This study makes three contributions. First, it holistically examines the individual's experience during marketing learning and the importance of its constituent components. Second, it establishes what the consequences of the marketing learning experience are, taking into account both social and individual factors, that is, collaborative learning and individual performance. Third, Pinterest is proposed as a social network with great potential in marketing learning. It is a wellknown network which includes very interesting features for learning contexts. Nevertheless, it has been little studied in research.
\end{abstract}

Keywords Social networks, Experience, Cognitive absorption, Pinterest, Marketing learning performance Paper type Research paper

(C) Miguel Guinaliu-Blasco, Blanca Hernández-Ortega and José L. Franco. Published in Spanish Journal of Marketing - ESIC. Published by Emerald Publishing Limited. This article is published under the Creative Commons Attribution (CC BY 4.0) licence. Anyone may reproduce, distribute, translate and create derivative works of this article (for both commercial and non-commercial purposes), subject to full attribution to the original publication and authors. The full terms of this licence may be seen at http://creativecommons.org/licences/by/4.0/legalcode

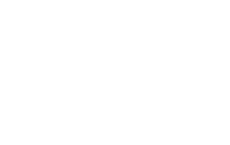




\section{Resumen}

Propósito - El objetivo de la presente investigación es analizar la experiencia del individuo durante el uso de Pinterest en un proceso de aprendizaje de marketing. Este experiencia es un punto de partida fundamental para que el proceso de aprendizaje de marketing se desarrolle de manera fluída. Así, es preciso examinar los componentes que determinan la experiencia del individuo y explorar las consecuencias, como por ejemplo, el aprendizaje colaborativo y los resultados del aprendizaje de marketing.

Diseño/metodología/enfoque - Con el objeto de conceptualizar la experiencia del individuo, este studio centra su atención en la absorción cognitiva $(\mathrm{AC})$ y propone una estructura formativa de segundo orden compuesta por cinco componentes: mayor disfrute, curiosidad, control, disociación temporal e inmersión enfocada. El modelo es estimado mediante el uso de Modelización de Mínimos Cuadrados Parciales, empleando el software SmartPLS 2.0.

Hallazgos - Los resultados confirman el significativo peso de los componentes, con la excepción de la inmensión enfocada, y apoya la influencia de la AC general sobre las consecuencias propuestas. Estos resultados también confirman que el aprendizaje colaborativo tiene una influencia positiva sobre los resultados del individuo.

Originalidad/valor - Este estudio ofrece tres contribuciones. En primer lugar, se examina de manera holística la experiencia del individuo durante el aprendizaje de marketing y la importancia de sus componentes. En segundo lugar, se establece cuales son las consecuencias de la experiencia de aprendizaje de marketing, teniendo en cuenta factores sociales e individuales, es decir, aprendizaje colaborativo y resultados individuales. En tercer lugar, se propone a Pinterest como una red social con un gran potencial en el aprendizaje de marketing. Se trata de una conocida red que incluye interesantes características para los contextos de aprendizaje. A pesar de ello, ha sido escasamente estudiada por los investigadores.

Palabras clave - Experiencia, Absorción cognitiva, Pinterest, Resultados de aprendizaje de marketing, Redes sociales

Tipo de artículo - Artículo de investigación

\section{Introduction}

The popularity of social networks in learning processes has led to new interactive environments that modify traditional approaches. Social networks combine education with entertainment, promote bidirectional communication and facilitate a wide variety of activities (Wang et al., 2012; Zhang and Daugherty, 2009). They enable learners and teachers to work together within a supportive community and build up appropriate knowledge through active participation (Ryu and Parsons, 2012). In this way, social networks create unique experiences, develop so-called "social learning", and promote the generation of benefits beyond traditional outcomes (Park et al., 2010).

From the marketing point of view, the use of social networks in the learning context has important advantages for customers (i.e. individuals) and for firms (i.e. educational institutions). Some studies have demonstrated that social networks improve the individual's consumption of learning services and optimize learning outcomes. For example, Abney et al. (2019) emphasised the importance of tools such as Twitter for stimulating debate between students and teachers in marketing learning. Kurthakoti et al. (2013) verified that using social networks increases the performance of work teams, while McCorkle and McCorkle (2012) concluded that LinkedIn helps individuals to acquire transversal skills, such as social communication and creativity. Social networks improve the quality of the relationships that educational institutions establish with students, because they enhance the effectiveness of communication strategies (Clark et al., 2017; Peruta and Shields, 2017). Similarly, some authors have examined the role played by social networks in the recruitment and retention of students by educational institutions (Constantinides and Zinck Stagno, 2011; Galan et al., 2015). These authors noted that the combination of asynchronous communication tools, such as Facebook, and face-to-face classes, fostered student-institution engagement (Northey et al., 2015). Overall, it has been found that social networks improve the 
individual's cognitive processes, boost her/his satisfaction and, in the context of educational institutions, generate various benefits, for example, customer engagement, long-term relationships and positive word of mouth.

Despite the opportunities that social networks offer in the learning context, research into their significance and influence is scarce and has focused usually on very few platforms, for example, Facebook, Twitter and LinkedIn. This previous research has generally applied a technological approach, studying consequences such as the user's perceptions about technology (e.g. ease of use, usefulness, enjoyment, etc.), attitude, satisfaction and intention to continue to use it (Chintalapati and Daruri, 2017; Milosevic et al., 2015; Sharma et al., 2016). In spite of the differences among the proposed models, in terms of the specific factors and relationships posited, there is consensus that the individual's perceptions of a technology are significant predictors of use. Nevertheless, this prior research has overlooked the importance of the individual's experience of social networks in learning processes. This prior experience might explain why the same network may provide effective learning in certain situations but not in others. Therefore, the concept of experience emerges as a key factor for understanding customer behaviour and optimising the learning process.

Experiences originate from a set of interactions between the individual and a product, an activity, a firm, or any other stimulus that provokes a reaction (LaSalle and Britton, 2003; Shaw and Ivens, 2005). They are personal in nature and involve the individual at different levels, including the rational, emotional, sensorial, physical and spiritual. In the learning context, several conditions determine whether experiences are successful. For instance, technological dimensions, the types of knowledge sought, and the methodologies applied, differentially influence the individual's cognitive processes and experiences (Gupta and Bostrom, 2009). Experiences can manifest themselves in several ways, such as enjoyment (Lin et al., 2012; Lin and Gregor, 2006), authenticity (Hall, 2009; Herrington et al., 2010) and emotions (Baumeister et al., 2015; Finch et al., 2015). Learning experiences in social networks differ from other computer-mediated experiences because of their dual character. On the one hand, social networks foster experiences in which the individual exhibits immersive behaviour and independently frames her/his own learning. On the other hand, social networks provide experiences that engage several actors in shared activities, supported by group collaboration. Educational institutions should take this dual nature into account in managing individuals' reactions and the relationships that develop through social networks.

The aim of the present study is to analyse the experience of the individual during the use of a social network in marketing learning. This experience is a fundamental starting point from which to develop a cognitive process that flows naturally. In this context, it is necessary to address two important issues. First, this study conceptualizes the marketing learning experience. To do so, it focuses on the individual's state of cognitive absorption (CA), taking the definition proposed by Agarwal and Karahanna (2000) as a starting point, and examines what components determine the experience. Second, it analyses the consequences of the marketing learning experience, exploring whether the $\mathrm{CA}$ that the individual feels leads her/him to participate in collaborative learning and, in turn, improves her/his performance. The social network studied is Pinterest, which differs from other social networks because it is principally based on images. Thus, the cognitive processes and the marketing learning that individuals experience with Pinterest are very different from those analysed in previous literature.

This paper has three main implications. First, in contrast to previous research based on the technological acceptance of social networks, it holistically examines the individual's experience during marketing learning and the importance of its constituent components. Second, it establishes what the consequences of the marketing learning experience are, 
SJME

23,2

Figure 1.

Research focus and contribution taking into account both social and individual factors, that is, collaborative learning and individual performance. Third, Pinterest is proposed as a social network with great marketing learning potential. It is a well-known network, but little studied in marketing learning research. It has a highly visual character and, as discussed below, includes a set of very interesting features for marketing learning contexts. Figure 1 depicts these contributions. Moreover, the findings of the present study provide important managerial contributions that may guide educational institutions in the design of their learning services and the definition of their marketing strategies.

\section{What is Pinterest? An ideal marketing learning tool}

Pinterest is a social network and smartphone application that enables its users to publish visual bookmarks and content links, called "pins". These "pins" can be images, pictures, diagrams, videos and infographics, either created by the user or obtained from other websites. Publications are organised on boards, categorised by topic; they can be individual or collective and private or viewable by other Pinterest users. Individuals can "follow" other users, allowing them to view automatically updated "pins" feeds posted by fellow users (Kim et al., 2017). The relationships among Pinterest users are asymmetric; individuals can "follow" other users without their consent or reciprocity (Ottoni et al., 2013). Moreover, Pinterest offers users several options to share and manage content, including re-send (repin), likes, shares in other networks, save and comment.

Although Pinterest is one of the youngest social networks, having been launched officially in 2010, it is one of the most globally popular. It has more than 250 million monthly

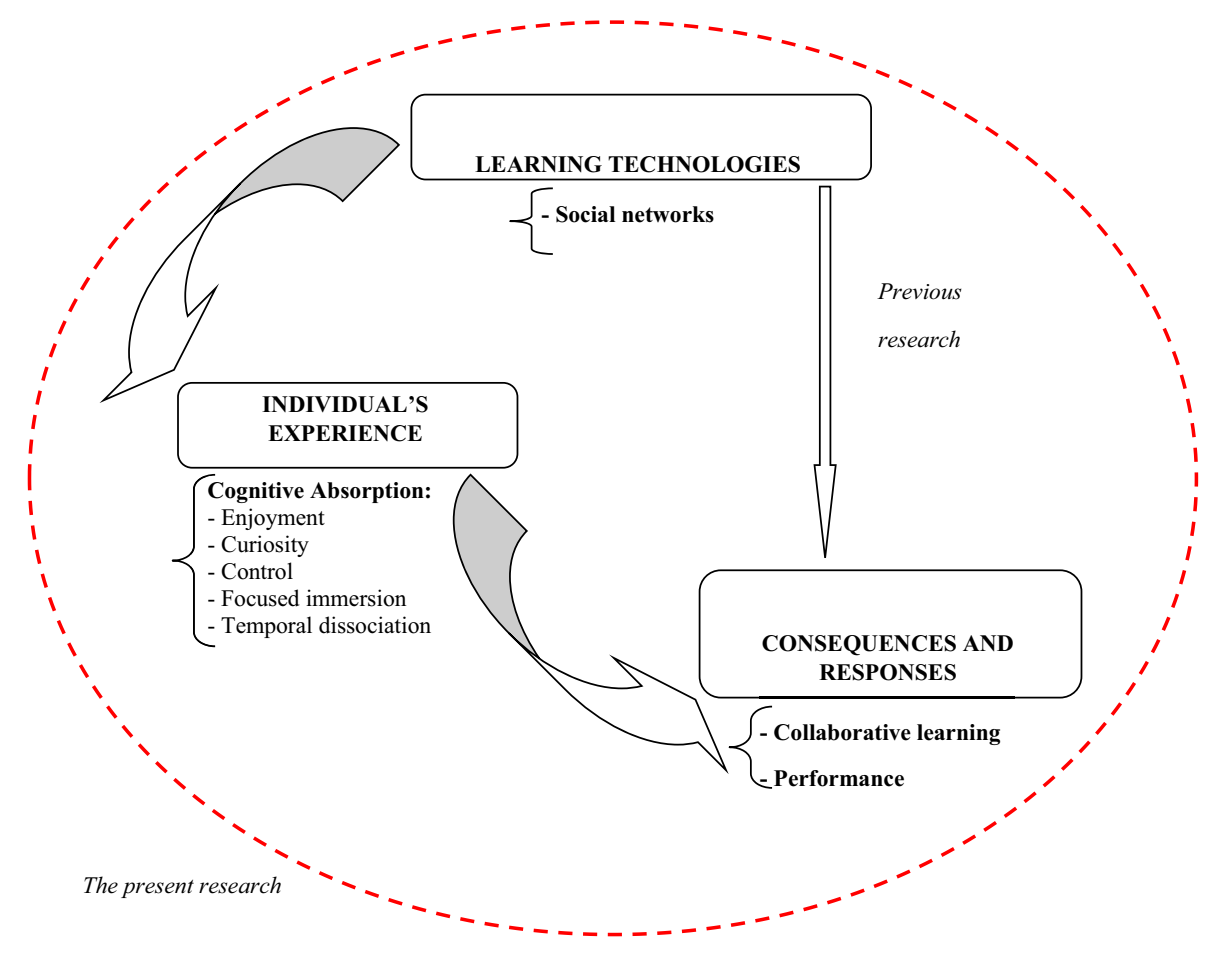


active users (Griffith, 2018) who have published more than 175 billion pins on more than 3 billion boards (Omnicore, 2019). Thus, Pinterest is one of the most intensively used social platforms. It is an environment in which users spend a lot of time sharing aspects of their personal life and "curing" images published by other users (Golbeck, 2015). This activity is especially popular among women and millennials (Aslam, 2017; Guimarães, 2014).

Some Pinterest characteristics differentiate it from other social networks and make it an interesting tool for marketing learning. First, Pinterest is primarily based on visual content, which allows users to transmit complex ideas and concepts visually. This feature greatly simplifies communication and fits well with the fact that 40 per cent of college students prefer visually-based learning (Clarke et al., 2006). Second, Pinterest is a very simple tool that provides several functionalities. It enables users to intuitively compile contents, organize and store ideas, and comment on other users' contributions. Third, Pinterest establishes easy and fast connections between users who are invited by the board creator to be collaborators and to add contents. In these cases the board is collaborative in nature because multiple users contribute and share knowledge in a community. Fourth, Pinterest boards stimulate ideas and inspire users as a consequence of the personalisation of the content and the organisation of the information (Caines, 2012). Pinterest is an environment where users discover and save creative content to access later.

Pinterest boasts several examples of interesting learning practices. Point Park University uses this social network to share visual content and develop collaborative exercises. Similarly, students at the University of Minnesota publish examples of designs and graphic works on Pinterest to generate new ideas. Finally, the University of Southern California has an official profile on the social network that publicizes different USC activities and topics. It also uses Pinterest in its entrepreneurship classes to enrich their traditional contents and examples. Thus, it can be concluded that Pinterest is an ideal tool to promote communication, to enhance individual creativity and to improve the marketing strategies of educational institutions.

\section{Conceptual framework and hypotheses}

The present study proposes a conceptual framework related to the application of Pinterest in marketing learning. This framework establishes that learners experience cognitive absorption (CA) during the use of this social network through different drivers. This experience acts as the starting point for the collaborative learning that ultimately enhances performance. Figure 2 shows a graphical representation of the conceptual framework.

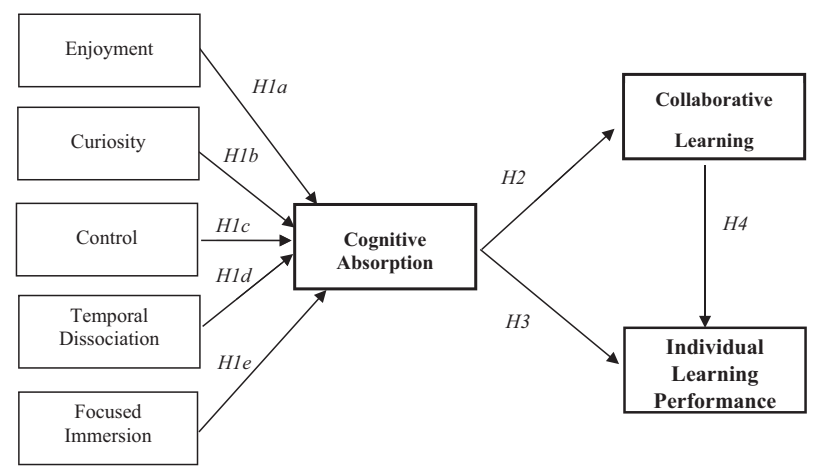

Figure 2. and hypotheses 
SJME

23,2

254

\subsection{Cognitive absorption}

Delivering superior and memorable experiences is one of the primary goals of marketing and a critical factor for the achievement of companies' long-term success (Lemon and Verhoef, 2016; Marketing Science Institute, 2016). Experiences offer a solid base from which to understand value creation and other outcomes (Gummerus, 2013; Papagiannidis et al., 2017), so academics and practitioners have emphasised the necessity of studying how experiences develop (Grönroos, 2015). Nevertheless, the complex nature of experiences leads to many definitions and concepts that should be examined when addressing this psychological process.

Cognitive absorption captures the state of deep involvement or the holistic experience that the individual feels during her/his interaction with a technology (Agarwal and Karahanna, 2000; Saadé and Bahli, 2005). This concept is supported by three interrelated theoretical pillars. First, the theory of flow (Csikszentmihalyi, 1990), described as "the state in which people are so involved in an activity that nothing else seems to matter" (p. 4). Flow state includes intense concentration, a sense of control, a loss of self-consciousness, and the transformation of time. It may occur when the individual is performing physical activities and when (s)he is interacting with symbolic systems. Second, cognitive absorption is connected with a personality trait dimension related to the individual's intrinsic propensity to be engrossed with an experience (Tellegen and Atkinson, 1974). This propensity leads the individual to experience episodes of total concentration where all one's resources are consumed by the object of attention. Third, cognitive absorption is related to the notion of cognitive engagement (Webster and Ho, 1997). Engagement has been defined as a multidimensional concept that encompasses the individual's intrinsic interest, curiosity and attention focus. It involves the individual filtering out irrelevant perceptions and thoughts, having control over the environment and losing self-consciousness (Liu et al., 2009).

Cognitive absorption is crucial in the learning context because it leverages individual intrinsic motivation during the process and promotes behaviour formation (Benbunan-Fich and Hilz, 2003). Previous research has analysed CA to understand the individual's learning experience with different technologies, such as online platforms (Saadé and Bahli, 2005; Leong, 2011), virtual worlds (Goel et al., 2013), virtual communities (Lin, 2009) and mobile technologies (Reychav and $\mathrm{Wu}, 2015 \mathrm{a}$ ). Nevertheless, CA has rarely been used to study the experience of using social networks in learning.

CA in social networks reflects the psychological process through which an individual is absorbed, is involved with other users, shares activities and generates computer-mediated experiences. Research into the individual's CA during the use of social networks is still young. To the best of our knowledge, the few existing studies apply a flow-based approach and use different components to measure the concept. Zhou et al. (2010) explored the influence of perceived enjoyment, control and attention, focusing on mobile social networks. Wu and Wang (2011) examined the perceived enjoyment, concentration, social interactions and escapism that the individual feels when using social networks. Finally, Kwak et al. (2014) studied the importance of the focused immersion, enjoyment, curiosity, telepresence and time distortion felt when using Facebook. It should be taken into account that these studies tested incomplete models; they considered the effects of only some of the CA dimensions proposed by Agarwal and Karahanna (2000). Thus, it is necessary to develop a comprehensive model specifically to measure the CA experienced in the employment of social networks in marketing learning.

The present study takes as its starting point the revised definition of CA proposed by Agarwal and Karahanna (2000) and, in contrast to previous research that considered experience as a one-dimensional factor, it breaks the concept down into five components. It 
combines an affective component, namely, heightened enjoyment, and four cognitive components, namely, curiosity, control, temporal dissociation and focused immersion (Wakefield and Whitten, 2006). These components reflect different kinds of experience that the individual can have during her/his interaction with a social network, and they exert different impacts on the formation of the overall state that the individual feels during learning. The present study advises that CA should be conceptualised as a second-order formative factor, shaped by first-order components that determine different kinds of experience. Other studies that have also examined the formative structure of CA are Pelet et al. (2017) for social media and Pallud (2017) for the role of interactive technologies in stimulating learning experiences. In accordance with their ideas, the present study tests the importance of each CA component during the employment of Pinterest and proposes different hypotheses for each of these components.

Heightened enjoyment captures the pleasurable aspects of an interaction, regardless of the performance consequences resulting from the use of the technology (Akman and Mishra, 2017; Domina et al., 2012). It addresses the hedonic benefits derived from the employment of specific technologies. Its effect has been included in the technology acceptance model, being compared with other extrinsic motivations, such as perceived usefulness and ease of use (Hsu and Lin, 2008; van der Heijden, 2004). Given the importance of this factor, some authors, for example, Weniger and Loebbecke (2011), have argued that enjoyment is more than a mere dimension of cognitive absorption and recommend that it should be studied as a separate construct. The present study proposes that the higher is the individual's feeling of enjoyment while using a social network in learning, the higher is her/his CA. Thus, the following hypothesis is stated:

H1a. The heightened enjoyment experienced by an individual while using Pinterest in marketing learning positively determines her/his overall cognitive absorption.

Curiosity refers to the extent to which an experience arouses an individual's sensory and cognitive interest (Rouibah, 2008). It addresses the individual's recognition, pursuit and desire to explore novel, uncertain, complex and ambiguous events. Curiosity combines the inquisitiveness and technical competence that the individual feels while (s)he is engaged in an action, including her/his desire for deeper insights into a subject (Kashdan et al., 2018; Moon and Kim, 2001). If the individual experiences curiosity in the employment of social networks during the learning process, (s)he will be motivated to continue the process to discover what happens after each interaction. Thus, the present study proposes that curiosity increases overall cognitive absorption:

H1b. The curiosity experienced by an individual while using Pinterest in marketing learning positively determines her/his overall cognitive absorption.

Control represents the individual's perception of being in charge of a situation. It refers to the individual's perception of her/his ability to successfully employ a technology and how the technology responds to her/his inputs. This perception is derived from the individual's beliefs about the presence or absence of her/his own skills, opportunities and resources necessary for the development of the analysed behaviour (Ajzen and Madden, 1986). If the individual feels that (s)he is controlling her/his interaction with the social network, (s)he will be relaxed and feel greater cognitive absorption. The following hypothesis is thus posited:

H1c. The control experienced by an individual while using Pinterest in marketing learning positively determines her/his overall cognitive absorption. 
SJME

23,2

256

Temporal dissociation addresses the individual's inability to register the passage of time while interacting with a technology. It is connected with flow constructs, such as telepresence and time distortion (Rutkowski et al., 2007) and transformation of time (Csikszentmihalyi, 1990). Individuals who are in a state of temporal dissociation perceive that time seems to stand still while they are engaged in an action (Csikszentmihalyi, 1990; Lee et al., 2012; Skadberg and Kimmel, 2004). Hence, although objectively time is measured by the clock, these individuals perceive time subjectively (Lobler et al., 2011; Tan et al., 2015). Therefore, the individual's belief that a short amount of time has passed is directly correlated with the fact that a longer amount of time has actually passed (Brooks and Longstreet, 2015). The present study proposes that the temporal dissociation that the individual feels during her/his interaction with the social network increases the cognitive absorption that (s)he experiences during the learning process. So, the following relationship is hypothesised:

H1d. The temporal dissociation experienced by the individual while using Pinterest in marketing learning positively determines her/his overall cognitive absorption.

Finally, focused immersion represents the complete immersion and engagement that the individual experiences during an interaction, during which other attentional demands are ignored. If the individual feels focused immersion, her/his attention is completely taken up by the action and nothing else matters (Pelet et al., 2017). Thus, the greater the focused immersion the individual experiences during her/his interaction with the social network, the more attention (s)he will pay to the learning activity and the greater will be her/his cognitive absorption. The following hypothesis is thus stated:

H1e. The focused immersion experienced by the individual while using Pinterest in marketing learning positively determines her/his overall cognitive absorption.

\subsection{The relationships between cognitive absorption, collaborative learning and marketing learning performance}

As already explained, the present study considers that CA is the psychological state that the individual experiences during the employment of a social network during learning. In this context, CA involves the learner going through a cognitive experience that flows naturally, characterised by the presence of, and collaboration with, other users, and that promotes her/ his active participation and conditions her/his behaviour (Reychav and Wu, 2015a). Specifically, the present study analyses the influence of CA on collaborative learning and marketing learning performance.

Collaborative learning is defined as a teaching and learning philosophy that involves sharing knowledge, experiences and authority, in which students teach and learn from each other and which generates positive interdependence (Panitz, 1996). It occurs when students work together in small groups towards a common goal, construct meaning, explore topics and improve skills (Harasim et al., 1995; Miranda and Saunders, 2003; Prince, 2004). According to connectivism theory, collaboration in learning involves the distribution of knowledge across a network of connections, so results depend on individuals' ability to traverse these networks (AlAbri et al., 2017). This kind of learning increases the individual's ability to think critically, to solve problems and to acquire specialist expertise (Angeli et al., 2003; Garrison et al., 2001). Moreover, it encourages students to participate by providing examples, explaining concepts and justifying their opinions (Lantz, 2010). Therefore, collaborative learning enables students to become active agents and to collaborate in knowledge creation (Draper et al., 2002; Dufresne and Gerace, 1996; Kennedy and Cuts, 2005). 
Social networks offer enormous possibilities to connect people through chats, discussions and forums, promoting enhanced collaborative learning experiences (Al-Abri et al., 2017; AlKhanjari et al., 2011). Nevertheless, the relationship between CA and collaborative learning in social networks has yet to be explored. Some studies have examined the relationship between cognitive engagement, the precursor concept of CA, and learning outcomes in technologymediated environments (Blasco et al., 2013; Webster and Hackley, 1997). They demonstrated that the greater the individual's engagement during learning, the better will be the obtained outcomes. The present study proposes that this relationship also exists for CA; the social experience of the individual during her/his interaction with other learners in social networks will encourage collaborative learning (Goel et al., 2013; Reychav et al., 2015; Reychav and Wu, 2015b). Social networks allow the individual to have experiences in which learners and teachers converse with each other, ask questions and share descriptions of the learning content, in a socio-dialogical process (Ryu and Parsons, 2012). The greater the absorption the individual experiences during the marketing learning process, the more (s)he participates and the better (s) he performs. On the contrary, if the individual does not experience cognitive absorption during her/his interaction with others on the social network, the less (s)he participates in the process, collaborative learning is inhibited, and the individual has poorer marketing performance. The following relationships are hypothesised:

H2. Cognitive absorption as a result of using Pinterest improves the individual's collaborative learning.

H3. Cognitive absorption as a result of using Pinterest improves the individual's marketing learning performance.

Previous research has demonstrated that collaborative learning influences outcomes to a greater extent when it is combined with the use of social technologies (Huang et al., 2014; Reychav and Wu, 20015 b; Stowell and Nelson, 2007). Their research assumes that, as people learn or work together and use technologies, the instantaneous nature of the technologies improve learning outcomes. For instance, Alavi (1994) showed that students using group decision support systems had greater interest, developed more skills and reported higher overall evaluations. Technologies encourage critical thinking and facilitate the understanding of educational materials (Agarwal and Venkatesh, 2002). In this context, social networks provide complete platforms that mediate the communication between actors, improve their coordination and provide interesting knowledge-generation opportunities. So, learners are impelled to generate knowledge not only for themselves but also for others, to jointly develop shared meanings and to achieve common goals (Jonassen and Land, 2000).

The present study agrees that interactions through technology, in general, and through social networks, in particular, are essential in collective learning. Nevertheless, the authors go further by proposing that collaboration between marketing learners also encourages the positive consequences that the individual derives from the learning activity. The individual's experience integrates collaborative learning with internal cognition, making her/him more aware of her/his mental processes and, thereby, enhancing relevant mental activities such as thinking, feeling and remembering (Ryu and Parsons, 2012). Consequently, individuals who use technologies to develop collaborative learning tend to experience a higher level of cognition (Pallud, 2017; Yoo et al., 2002). In accordance with these arguments, the following hypothesis is proposed:

H4. Collaborative learning undertaken using Pinterest improves the individual's marketing learning performance. 
SJME

23,2

\section{Method: procedure, participants and measures}

This study was developed from an academic activity based on Pinterest. The activity was carried out by university students enrolled in marketing degree courses at a major Spanish university during eight weeks in March and April 2017.

During the first week, teachers introduced the activity over several classes and explained the objectives, rules and schedule. The students interested in participating had two weeks to register by filling out a Google Drive form. They took part voluntarily and worked in groups of two or three.

The activity, which had a contest format, was related to three new marketing trends, viral marketing, cause marketing and experiential marketing. The teachers created a Pinterest board for each trend, registered the participants and sent an invitation e-mail to each group. The groups then had four weeks to search outside the class for real business examples and to find practices related to these marketing trends. When they found examples, the students captured them through photo or video and published them on the Pinterest board. Although the three boards could be viewed by other Pinterest users, only groups that had accepted the invitation could post material. Each group had to pin a minimum of one publication on each marketing trend board.

As the effectiveness of Pinterest for enhancing learning depended to a great extent on the examples published by the groups, special attention was paid to this stage. The contents were evaluated by the teachers very soon after publication, so the students knew, almost in real time, whether the example was suitable. Moreover, students could interact with, and give their opinion on the examples of, their peers by sharing, commenting on or re-pinning them. These interactions were very important; the students evaluated the work of their peers and learned through the examples found by others. For this reason, the teachers constantly encouraged the students to evaluate and revise the pins of the other groups and to ask questions about the examples. The interactions between peers and the teachers were aimed at improving the students' understanding of the marketing trends and enhancing their capacity to apply their knowledge to real situations.

The results were very positive: 190 students, who formed 84 groups, participated in the activity. The viral marketing trend board received 213 pins and 106 followers (https:/es. pinterest.com/mkviraluz/marketing-viral/), the experiential marketing trend board received 237 pins and 110 followers (https://es.pinterest.com/Experiencialmar/marketing-experiencial/), and the cause marketing trend board received 187 pins and 108 followers (https://es.pinterest. com/fdfhfjjj/marketing-con-cause/).

During the last week of the activity, an e-mail survey was undertaken to assess the students' opinions about the use of Pinterest. In total, 157 valid responses were obtained, that is, an 82.6 per cent response rate. Of these, 55.4 per cent were between 19 and 23 years old and 76.4 per cent were women. It should be noted that, although the percentage of women may appear high, Pinterest is used more by women than men. Therefore, this percentage increases the significance of the sample. It should also be highlighted that only 5.7 per cent of participants were regular users of Pinterest, compared to the 83.4 per cent that used other social networks several times daily. This adds value to the activity because very few were accustomed to using Pinterest.

A literature review was carried out to measure the constructs used in the study (Table I). Seven-point scales were used in all cases. Measures of factors that determine cognitive absorption, that is, heightened enjoyment, control, curiosity, temporal dissociation and focused immersion, were obtained from Agarwal and Karahanna (2000) and Reychav and $\mathrm{Wu}$ (2015b). Collaborative learning was measured by adapting the scales of Blasco et al. 


\begin{tabular}{lcccc}
\hline & Factor & Boots & & \\
Measures & loading & t-value & CRC & AVE \\
\hline
\end{tabular}

Heightened enjoyment (Agarwal and Karahanna, 2000; Reychav and Wu, 2015b)

During the realization of this activity ...

ENJ1 . . . I enjoyed interacting in Pinterest

ENJ2 . . . Pinterest provided me a lot of enjoyment

ENJ3 ... I had fun

$\begin{array}{ll}0.91^{*} & 15.04 \\ 0.92^{*} & 13.15 \\ 0.93^{*} & 14.73\end{array}$

$0.94 \quad 0.85$

259

Curiosity (Agarwal and Karahanna, 2000; Reychav and Wu, 2015b)

The realization of this activity ...

CUR1 .. . excited my curiosity

CUR2 . . . aroused my imagination

$0.83^{*} \quad 12.02$

$0.86^{*} \quad 11.66$

CUR3 ... made me curious

$0.80 * \quad 8.19$

$0.87 \quad 0.69$

Control (Agarwal and Karahanna, 2000; Reychav and Wu, 2015b)

During the realization of this activity, I felt that ...

CONT1 . . .everything was under control

$0.80 * \quad 13.76$

CONT2 ... I had control of the situation

$0.94 * \quad 16.46$

CONT3 ... I controlled my interactions in Pinterest

$0.81 * \quad 11.40$

$0.88 \quad 0.73$

Temporal dissociation (Agarwal and Karahanna, 2000; Reychav and Wu, 2015b)

During the realization of this activity. .

$\begin{array}{lll}\text { TEDI1 ... time appeared to go very quickly } & 0.91^{*} & 15.15\end{array}$

$\begin{array}{lll}\text { TEDI2 . . time flied } & 0.97 * & 20.79\end{array}$

$\begin{array}{lll}\text { TEDI3 ...I lost track of time } & 0.78^{*} & 12.69\end{array}$

$0.92 \quad 0.79$

Focused immersion (Agarwal and Karahanna, 2000; Reychav and Wu, 2015b)

During the realisation of this activity...

FI1 ... I was able to block out most other distractions $\quad 0.84^{*} \quad 14.31$

FI2 . . I was absorbed in what I was doing $\quad 0.86^{*} \quad 14.43$

FI3 . . my attention did not get diverted very easily $\quad 0.85^{*} \quad 13.25$

$0.89 \quad 0.73$

Collaborative learning (So and Brush, 2008; Blasco et al., 2013)

During this activity with Pinterest, I felt that. . .

$\begin{array}{lll}\text { CL1 . . I actively collaborated in my learning experience } & 0.87^{*} & 11.55\end{array}$

CL2 . . . I had free rein to co-create my own learning experience $\quad 0.94 * \quad 13.41$

$\begin{array}{lllll}\text { CL2 ... I had free rein to co-create my own learning experience } & 0.94^{*} & 13.41 & & \\ \text { CL3 ... had freedom to participate in my own learning experience } & 0.92^{*} & 12.25 & 0.94 & 0.83\end{array}$

Learning performance (MacGeorge et al., 2008)

I consider that my participation in this activity has allowed me...

LP1 ... to improve my comprehension of marketing concepts

LP2 ... to understand marketing activities carried out by real firms

LP3 ... to identify marketing strategies and techniques in the real world

LP4 ... to increase my marketing knowledge

Effect of cognitive absorption

Notes: $\mathrm{CRC}=$ Composite reliability coefficient; $\mathrm{AVE}=$ Average variance extracted $* p<0.01$

$\begin{array}{lrrr}0.82^{*} & 10.68 & & \\ 0.85^{*} & 7.90 & & \\ & & & \\ 0.92^{*} & 10.32 & & \\ 0.88^{*} & 10.52 & 0.92 & 0.75\end{array}$

Table I.

Scales and confirmatory analyses

(2013) and So and Brush (2008). Learning performance was assessed following Blasco et al. (2013) and MacGeorge et al. (2008).

\section{Measurement model assessment, second-order formative factor and results}

To estimate the proposed model the reliability and validity of the measurement model was first evaluated. Given the size of the sample and the second-order formative factor proposed 
SJME

23,2

260

to measure cognitive absorption, partial least squares modelling was used (Tenenhaus et al., 2005) with SmartPLS 2.0 software.

Table I shows the results of the evaluation of reliability and convergent validity. The indicators show high internal consistency. In all cases, the composite reliability coefficient, which represents the variance shared between indicators measuring the same construct (Fornell and Larcker, 1981), reached the minimum value of 0.70 (Bagozzi and Yi, 1988). Similarly, the average variance extracted (AVE) exceeds the value of 0.50 for all constructs (Fornell and Larcker, 1981).

As evidence of convergent validity, the results show that all the indicators are significant $(p<0.01)$ and their standardised loadings are higher than 0.70 (Bagozzi and Yi, 1988). Discriminant validity was evaluated (Table II), confirming that the squared root of the AVE (reported on the diagonal) of one construct is always greater than the inter-construct correlations (the off-diagonal) (Fornell and Larcker, 1981).

Thus, it can be concluded that the scales used to measure the reflected first-order constructs exhibit sufficient evidence of reliability and convergent and discriminant validity.

The next step examined the formative second-order construct of cognitive absorption. First, the correlations among the first-order constructs (i.e. heightened enjoyment, curiosity, control, temporal dissociation and focused immersion) were examined. High correlations suggest that first-order constructs are measuring the same aspect of the construct, so they should be reflective (Peter et al., 2007). As shown in Table II, this was not the case for the first-order constructs that determine cognitive absorption because the correlation between them is always less than 0.80 (Pavlou and El Sawy, 2006). Second, the multicollinearity between the first-order constructs is tested to ensure the model is not destabilised (Diamantopoulos and Winklhofer, 2001) and cause the weights to be to be non-significant (Hair et al., 2011). To ensure that multicollinearity was not present, the variance inflation factor (VIF) was calculated for the means of the first-order constructs. The values obtained varied from 1.04 to 2.55, which is far below the common cut-off threshold of 5 (Hair et al., 2011). Thus, it can be stated that the second-order construct for cognitive absorption is formative, as theoretically proposed (Urbach and Ahlemann, 2010).

Figure 3 shows the results of the analyses carried out to test the proposed hypotheses. In line with the recommendations of Hair et al. (2012), bootstrapping was applied (5,000 subsamples of the same size) to obtain standard errors and $t$-values to evaluate the significance of the parameters.

Regarding cognitive absorption, the weights of all the first-order constructs are significant (Chin, 1998; Diammantopoulos and Winklhofer, 2001; Hair et al., 2011) (Table III).

Table II.

Correlations and discriminant validity

\begin{tabular}{lccccccr}
\hline & 1 & 2 & 3 & 4 & 5 & 6 & 7 \\
\hline 1. Enjoyment & 0.92 & & & & & & \\
2. Curiosity & 0.76 & 0.83 & & & & & \\
3. Control & 0.43 & 0.47 & 0.85 & & & & \\
4. Temporal dissociation & 0.58 & 0.54 & 0.46 & 0.89 & & & \\
5. Focused immersion & 0.40 & 0.41 & 0.40 & 0.57 & 0.85 & & \\
6. Collaborative learning & 0.67 & 0.64 & 0.53 & 0.48 & 0.39 & 0.91 & \\
7. Learning performance & 0.62 & 0.67 & 0.49 & 0.38 & 0.33 & 0.64 & 0.87
\end{tabular}

Notes: In italics, the square roots of average variance extracted. The correlations among constructs are below the diagonal elements 


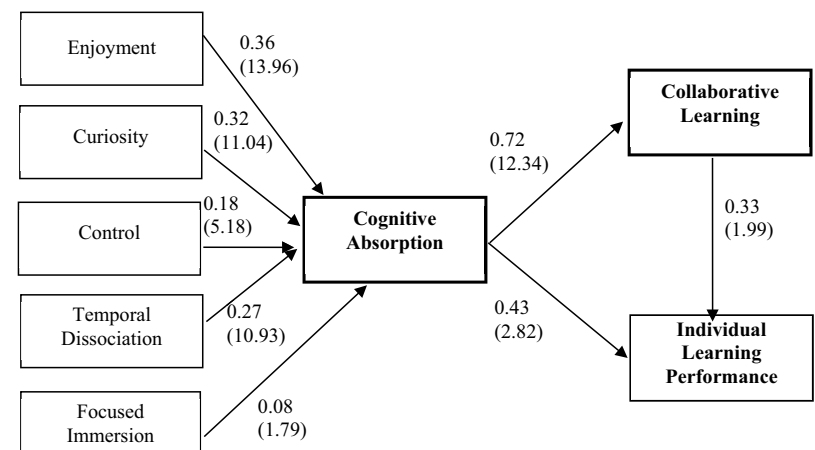

\begin{tabular}{llcc}
\hline Second-order construct & First-order constructs & Weight & $t$-statistic \\
\hline Cognitive absorption & & & \\
& Enjoyment & 0.36 & $14.28^{* * * *}$ \\
& Curiosity & 0.32 & $11.15^{* * *}$ \\
& Control & 0.18 & $5.11^{* * *}$ \\
& Temporal dissociation & 0.27 & $11.16^{* * *}$ \\
& Focused immersion & 0.08 & $1.75^{*}$
\end{tabular}

Notes: ***Significant at 0.01 level based on 5,000 bootstraps; **significant at 0.05 level based on 5,000 bootstraps; *significant at 0.1 level based on 5,000 bootstraps

Table III.

Weights of the firstorder constructs on the second-order construct

Nevertheless, it should be noted that focused immersion has a weight of less than 0.1 ; thus, it is rejected. The other constructs obtained a weight above the limit of 0.1 , so their effects on cognitive absorption were confirmed, heightened enjoyment and curiosity being the most important drivers. $H 1 a, H 1 b, H 1 c$ and $H 1 d$ are supported, but $H 1 e$ is rejected.

The indirect and total effects of all the constructs on learning performance were also examined, because they provide interesting information about cause-effect relationships (Table IV). The effect of cognitive absorption on collaborative learning is highly significant $(\beta=$ $0.72, p<0.01)$, as is the total effect of the former on learning performance $(\beta=0.67, p<0.01)$.

\begin{tabular}{lcccc}
\hline Construct & Direct effects & Indirect effects & Total effects & $t$-Statistic (total effects) \\
\hline Enjoyment & - & 0.24 & 0.24 & $8.13^{* * * *}$ \\
Curiosity & - & 0.22 & 0.22 & $7.06^{* * * *}$ \\
Control & - & 0.12 & 0.12 & $4.27^{* * * *}$ \\
Temporal dissociation & - & 0.18 & 0.18 & $7.31^{* * *}$ \\
Focused immersion & - & 0.06 & 0.06 & $1.74^{*}$ \\
Cognitive absorption & 0.43 & 0.24 & 0.67 & $8.04^{* * *}$ \\
Collaborative learning & 0.33 & - & 0.33 & $1.99^{* *}$
\end{tabular}

Notes: Learning performance: $R^{2}=0.41 ; \mathrm{Q}^{2}=0.33$; Collaborative Learning: $R^{2}=0.51 ; \mathrm{Q}^{2}=0.44$; *** Significant at 0.01 level based on 5,000 bootstraps; ***ignificant at 0.05 level based on 5,000 bootstraps; *significant at 0.1 level based on 5,000 bootstraps

Table IV.

Direct, indirect and total effects on learning performance 
SJME

23,2

262

Finally, collaborative learning also significantly influences individual learning performance $(\beta=0.33 ; p<0.05)$. H2, H3 and $H 4$ are confirmed.

Although the $R^{2}$ of the dependent variables exceeded the value of 10 per cent suggested by Falk and Miller (1992), power analysis was also tested by G*Power (Faul et al., 2007) to confirm the endogenous constructs' predictive relevance (Cohen, 1988). The positive blindfolding $\mathrm{Q}^{2}$ statistic obtained by collaborative learning and learning performance demonstrates the predictive relevance of the proposed model (Geisser, 1975; Stone, 1974).

\section{Conclusions: discussion, managerial contributions, future research lines and limitations}

6.1 Discussion

As more and more educational institutions integrate social networks into their marketing learning systems to enhance the learning process, it becomes increasingly necessary to thoroughly understand the mechanisms behind the effect of these networks on the individual's performance. Although there has been a recent increase in research into the influence of social networks on student learning, several gaps remain and prevent us from having a complete understanding of this phenomenon, offering researchers new opportunities.

The primary objective of the present study is to analyse the effect of the learner's experience during the use of a social network in her/his marketing learning process. Drawing upon previous research, a conceptual framework was formulated in which the components and nature of experience were addressed through the concept of cognitive absorption. This concept, which influences collaborative learning and marketing learning performance, is made up of five components, heightened enjoyment, curiosity, control, temporal dissociation and focused immersion. The framework was tested through a teaching activity based on Pinterest that encouraged the learners to identify real marketing examples. The model was tested by a survey answered by 157 marketing degree undergraduates. The results obtained from the empirical analyses provided strong support for the proposed model and enable important conclusions to be drawn.

The results demonstrated that four of the five components of CA significantly determine the individual's experience when using Pinterest in marketing learning, the most important being heightened enjoyment and curiosity. Thus, it can be stated that, when the individual enjoys interacting on the social network and is curious about the activity and the content generated, (s)he has a rewarding experience and achieves greater cognitive absorption. These findings are similar to those obtained in previous research (Pallud, 2017; Pelet et al., 2017), which highlights the importance of these factors as antecedents of the individual's cognitive engagement with interactive technologies in the learning context. The importance of enjoyment and curiosity is consistent with the significant role of the emotional processes that explain the student's continuance intentions in online learning (Guo et al., 2016; Rodríguez-Ardura and Meseguer-Artola, 2016). Moreover, "enjoyment of using digital learning" is one of the "four blue ocean themes" that Liu (2008, p. 745) identified as deserving of more detailed examination. Therefore, by testing the role of enjoyment and curiosity, the present study impacts not only on marketing but also on educational theory.

Feelings of control and temporal dissociation are also important for the individual to experience cognitive absorption. Findings are consistent with previous studies that demonstrated that individuals should feel capable of controlling their own actions in learning processes (Esteban-Millat et al., 2014; Reychav and Wu, 2015a). These studies verified that perceived control is an important driver of the individual's emotions (Pekrun, 2006), academic motivations (Martinez, 2003) and performance (Ruthig et al., 2008). 
Similarly, the significance of temporal dissociation is associated with the alteration of the passage of time perceived by individuals when going through certain learning processes using technologies. This perception is related to the high level of concentration that individuals feel during the interaction, which makes them cut off temporarily, as demonstrated by Lee (2010). Temporal dissociation will make the individual think (s)he has finished a task in less time than it actually took (Saadé and Bahli, 2005).

Otherwise, focused immersion is not important in the configuration of CA. This finding is in significant contrast to other works that have highlighted the importance of focused immersion in technology use, such as mobile multimedia and online learning (EstebanMillat et al., 2014; Pallud, 2017; Reychav and Wu, 2015a). This difference probably exists because communication in social networks has a community structure that leads the individual to continuously interact with other users during the experience and thus not totally focus on the learning activity. On the contrary, processes supported by other asynchronous technologies, such as emails, forums and bulletin boards, allow individuals to take only one action and to focus on their own learning. These technologies do not require simultaneous interactions with other actors.

A noteworthy result of the present study is the recognition of the importance of CA in the improvement of the individual's learning performance. Baker et al. (2017) confirmed the importance of the individual's feeling of CA for causing positive perceptions about learning, CA being generated through interactive participation. Similar results were obtained by Reychav and $\mathrm{Wu}(2015 \mathrm{a})$ in a study about the role of CA in a mobile learning environment (a similar context to the present research, since Pinterest can be a mobile app). These authors noted that "the theory of cognitive absorption contributes to further understanding improvements in learning outcomes" (p. 343). CA is crucial to effective training, because it fosters individual motivation during the learning process and improves learning outcomes (Tharenou, 2001). It acts as the starting point of the cognitive process that influences the individual's learning and behaviour. Therefore, the greater is the CA experienced, the greater will be the collaboration of the individual with other users during marketing learning, and the better will be the final performance.

Moreover, the relationship between collaborative learning and individual learning performance is remarkable. As the learner interacts with her/his peers and with the marketing teacher through the social network, (s)he feels active in the marketing learning process and perceives that her/his contribution is building new knowledge. The collaborative learning that takes place on the social network allows the individual to create social bonds and encourages her/him to make the most of herself/himself. In this way, collaborative learning not only improves the group's performance but also optimizes the individual's performance. This finding is consistent with previous research (Blasco et al., 2013; Liao et al., 2015; Sung and Hwang, 2013).

It is important to point out that the individual's experience and its consequences depend on the social network used and the design of the activity. Pinterest is characterised by its originality and novelty, which influences the individual's overall evaluation of her/his experience and, especially, the enjoyment and curiosity that determine her/his cognitive absorption. The possibility of transmitting ideas through images, its ease of use, the organisation of themes by boards, and the interconnection between group members, make Pinterest an ideal social network for the development of marketing learning based on collaboration. Therefore, both the characteristics of Pinterest and the design of the activity motivated the marketing learners, improved their collaborative learning and optimised individual performance. 
SJME

23,2

In summary, it can be concluded that Pinterest is an interesting marketing learning tool through which to develop experiences based on enjoyment, curiosity, temporal dissociation and control. These experiences give rise to cognitive processes based on active student participation and collaborative learning, which improve individual performance.

\subsection{Managerial contributions}

The present study addresses the influence of Pinterest on marketing learning processes and demonstrates that this social network provides several benefits to learners and educational institutions. The findings enable several managerial contributions to be proposed. First, proposals are made about improvements that Pinterest may make to the services offered by educational institutions. These services are, in fact, the product that educational institutions offer to satisfy customer needs and to differentiate themselves from their competition. Second, proposals are made for managerial contributions related to the use of Pinterest to upgrade the marketing strategies of educational institutions.

Educational institutions might use Pinterest in the design of interactive, unique and pleasurable learning services. In recent years, individuals have become more likely than ever before to rely on pictorial information, so educational institutions should exploit the possibilities offered by new social networks, such as Pinterest, to redesign their learning services. Taking learners out of their comfort zones and breaking conventional structures increases their interest in learning. Pinterest can support the incorporation of several novelties: in the work space (out of the class), in the objective of the activity (real examples obtained from the internet), and in how results are presented (published on the social network). These developments allow institutions to create unique learning services to increase the individual's motivation and improve individual performance. For example, a student might carry out a study into a brand, create a board on Pinterest about the brand, collect related images and videos and thereby develop an entertaining and useful learning experience.

Educational institutions might apply Pinterest to develop learning processes based on the individual's cognitive absorption. Pinterest may lead individuals to feel enjoyment, curiosity, control and temporal dissociation during learning, thus experiencing a state of involvement that positively affects their performance. Thus, Pinterest should not be used only to achieve particular results, but also to develop enriching processes based on the individual's cognitive absorption. This form of learning process optimizes the individual's experiences and differentiates apparently similar services. For example, https://pingroupie.com is a tool that uses predefined filters or direct search to find boards on any subject. This not only allows interesting information to be obtained, it also facilitates the establishment of contacts with subject specialists.

Educational institutions might take advantage of the collaborative nature of their learning services and apply social networks, such as Pinterest, to promote a collective identity. Social networks encourage individuals to participate and create collaboration-based cognitive processes. This collaboration is achieved when all the elements that shape the learning experience are properly combined; in this, social networks can play a key role. Collaboration not only improves the group outcome as a whole but also enables each marketing learner to maximize her/his individual performance.

Educational institutions might disseminate their marketing strategies using social networks frequently used by their target audience as communication channels. Social networks that some years ago were considered fundamental to any marketing strategy, such as Twitter and Facebook, are becoming obsolete among young people. On the contrary, social networks based on photographs and images, such as Pinterest and Instagram, are 
emerging with real force and are frequently used by learners. They allow institutions to establish a direct dialogue with the learners. Moreover, they facilitate the dissemination of experiential messages, which increase the individual's enjoyment, curiosity and/or temporal dissociation during interactions. For example, Drake University has a complete profile on Pinterest (www.pinterest.es/drakeuniversity/) that includes several boards on different topics, such as life on campus, lifestyle and sports.

\subsection{Future research lines and limitations}

This study has some limitations that should be addressed in future research. First, the sample consisted only of students using Pinterest in their learning, and thus no comparisons were made with a control group not using Pinterest. This prevents the elimination of other potential explanations for the obtained results, such as the affinity of students for the subject. Thus, future research should develop a quasi-experiment to test the proposed framework across two different marketing learner groups, Pinterest users and non-users.

Second, given that this activity is a pioneer in the study of Pinterest in this marketing degree, the results may reflect, in some way, its novelty. None of the respondents had previously used this social network in learning. Consequently, their experience was conditioned by positive factors, such as curiosity, variety-seeking or the need for cognition, and by negative factors, such as laziness, the fear of making mistakes or lack of familiarity. Future research should examine the effect of Pinterest longitudinally to determine whether the effects obtained diminish as individuals' experience with this social network increases.

Third, the present study examines the Pinterest application. However, in recent years, similar applications have emerged, such as Snapchat and TikTok, as have new features in consolidated applications, such as Instagram stories. These applications have achieved great acceptance, especially among the young, and are characterised by the generation of private experiences - as opposed to the concept underpinning public social media platforms - of ephemeral duration, through the use of short videos or images that are erased within just a few hours. In future research, it would be interesting to evaluate the use of these applications in the development of successful marketing learning services and to compare the findings with those of the present study.

\section{References}

Abney, A.K., Cook, L.A., Fox, A.K. and Stevens, J. (2019), "Intercollegiate social media education ecosystem", Journal of Marketing Education, In Press.

Agarwal, R. and Karahanna, E. (2000), “Time flies when you're having fun: cognitive absorption and beliefs about information technology use", MIS Quarterly, Vol. 24 No. 4, pp. 665-694.

Agarwal, R. and Venkatesh, V. (2002), "Assessing a firm's web presence: a heuristic evaluation procedure for the measurement of usability", Information Systems Research, Vol. 13 No. 2, pp. 168-186.

Ajzen, I. and Madden, T.J. (1986), "Prediction of goal-directed behavior: attitudes, intentions and perceived behavioral control", Journal of Experimental Social Psychology, Vol. 22 No. 5, pp. 453-474.

Akman, I. and Mishra, A. (2017), "Factors influencing consumer intention in social commerce adoption", Information Technology and People, Vol. 30 No. 2, pp. 356-370.

Al-Abri, A., Jamoussi, Y., Kraiem, N. and Al-Khanjari, Z. (2017), "Comprehensive classification of collaboration approaches in e-learning", Telematics and Informatics, Vol. 34 No. 6, pp. 878-893.

Alavi, M. (1994), “Computer-mediated collaborative learning - an empirical evaluation”, MIS Quarterly, Vol. 18 No. 2, pp. 159-174. 
Al-Khanjari, Z.A., Kutti, N.S. and Dorvlo, A.S.S. (2011), "Promoting online learning through learners' vision", ACM Inroads, Vol. 2 No. 3, pp. 34-37.

Angeli, C., Valanides, N. and Bonk, C.J. (2003), "Communication in a web-based conferencing system: the quality of computer-mediated interaction", British Journal of Educational Technology, Vol. 34 No. 1, pp. 31-43.

Aslam, S. (2017), "Pinterest by the numbers: Stats, demographics and fun facts, omnicore", available at: www.omnicoreagency.com/pinterest-statistics/ (accessed 23 October 2018).

Bagozzi, R. and Yi, Y. (1988), "On the evaluation of structural equation models", Journal of the Academy of Marketing Science, Vol. 16 No. 1, pp. 74-94.

Baker, D.S., Underwood, J., III. and Thakur, R. (2017), "Factors contributing to cognitive absorption and grounded learning effectiveness in a competitive business marketing simulation", Marketing Education Review, Vol. 27 No. 3, pp. 127-140.

Baumeister, R.F., Alquist, J.L. and Vohs, K.D. (2015), "Illusions of learning: irrelevant emotions inflate judgments of learning”, Journal of Behavioral Decision Making, Vol. 28 No. 2, pp. 149-158.

Benbunan-Fich, R. and Hilz, S.R. (2003), "Mediators of the effectiveness of online courses", IEEE Transactions on Professional Communication, Vol. 46 No. 4.

Blasco, L., Buil, I., Hernandez, B. and Sese, J. (2013), "Using clickers in class. The role of interactivity, active collaborative learning and engagement in learning performance", Computers and Education, Vol. 62, pp. 102-110.

Brooks, S. and Longstreet, P. (2015), "Social networking's peril: cognitive absorption, social networking usage, and depression”, Cyberpsychology: Journal of Psychosocial Research on Cyberspace, Vol. 9 No. 4 , article 5 .

Caines, M. (2012), "What pinterest means for the arts", The Guardian, 24-II-12.

Chin, W.W. (1998), "Issues and opinion on structural equation modelling", MIS Quarterly, Vol. 22 No. 1, pp. 6-16.

Chintalapati, N. and Daruri, V.S.K. (2017), "Examining the use of YouTube as a learning resource in higher education: scale development and validation of TAM model", Telematics and Informatics, Vol. 34 No. 6, pp. 853-860.

Clark, M., Fine, M.B. and Scheuer, C. (2017), "Relationship quality in higher education marketing: the role of social media engagement", Journal of Marketing for Higher Education, Vol. 27 No. 1, pp. 40-58.

Clarke, I., Flaherty, T. and Yankey, M. (2006), "Teaching the visual learner: the use of visual summaries in marketing education", Journal of Marketing Education, Vol. 28 No. 3, pp. 218-226.

Cohen, E. (1988), "Authenticity and commoditization in tourism”, Annals in Tourism Research, Vol. 15 No. 3, pp. 371-386.

Constantinides, E. and Zinck Stagno, M.C. (2011), "Potential of the social media as instruments of higher education marketing: a segmentation study", Journal of Marketing for Higher Education, Vol. 21 No. 1, pp. 7-24.

Csikszentmihalyi, M. (1990), Flow, Harper and Row, New York, NY.

Diamantopoulos, A. and Winklhofer, H.M. (2001), "Index construction with formative indicators: an alternative to scale development", Journal of Marketing Research, Vol. 38 No. 2, pp. 269-277.

Domina, T., Lee, S.E. and MacGillivray, M. (2012), "Understanding factors affecting consumer intention to shop in a virtual world”, Journal of Retailing Consumer Services, Vol. 19 No. 6, pp. 613-620.

Draper, S.W., Cargill, J. and Cutts, Q. (2002), "Electronically enhanced classroom interaction", Australasian Journal of Educational Technology, Vol. 18 No. 1, pp. 13-23.

Dufresne, R.J. and Gerace, W.J. (1996), "Assessing-to-learn: formative assessment in physics instruction”, The Physics Teacher, Vol. 42 No. 7, pp. 428-433. 
Esteban-Millat, I., Martínez-López, F., Huertas-García, R., Meseguer, A. and Rodríguez-Ardura, I. (2014), "Modelling students' flow experiences in an online learning environment", Compters and Education, Vol. 71, pp. 111-123.

Faul, F., Erdfelder, E., Lang, A.G. and Buchner, A. (2007), "G * power 3: a flexible statistical power analysis program for the social, behavioral, and biomedical sciences", Behavior Research Methods, Vol. 39 No. 2, pp. 175-191.

Finch, D., Peacock, M., Lazdowski, D. and Hwang, M. (2015), "Managing emotions: a case study exploring the relationship between experiential learning, emotions, and student performance", The International Journal of Management Education, Vol. 13 No. 1, pp. 23-36.

Fornell, C. and Larcker, D. (1981), "Evaluating structural equation models with unobservable variables and measurement error", Journal of Marketing Research, Vol. 18 No. 1, pp. 39-51.

Galan, M., Lawley, M. and Clements, M. (2015), "Social media's use in postgraduate students' decisionmaking journey: an exploratory study”, Journal of Marketing for Higher Education, Vol. 25 No. 2, pp. 287-312.

Garrison, D.R., Anderson, T. and Archer, W. (2001), "Critical thinking cognitive presence, and computer conferencing in distance education", American Journal of Distance Education, Vol. 15 No. 1, pp. 7-23.

Geisser, S. (1975), "The predictive sample reuse method with applications", Journal of the American Statistical Association, Vol. 70 No. 350, pp. 320-328.

Goel, L., Johnson, N.A., Junglas, I. and Ives, B. (2013), "How cues of what can be done in a virtual world influence learning: an affordance perspective", Information and Management, Vol. 50, pp. 197-206.

Golbeck, J. (2015), Introduction to Social Media Investigation: A Hands-on-Approach, Elsevier, Amsterdam.

Griffith, E. (2018), "Pinterest is a unicorn. It just doesn't act like one", the New York times", available at: www.nytimes.com/2018/09/09/technology/pinterest-growth.html (accessed 9 March 2019).

Grönroos, C. (2015), Service Management and Marketing: managing the Service Profit Logic, John Wiley and Sons, Incorporated.

Guimarães, T. (2014), Pinterest's demographics mean it could become the next monster social advertising platform, Business Insider.

Gummerus, J. (2013), "Value creation processes and value outcomes in marketing theory: strangers or siblings?”, Marketing Theory, Vol. 13 No. 1, pp. 19-46.

Guo, Z., Xiao, L., Van Toorn, C., Lai, Y. and Seo, C. (2016), "Promoting online learners' continuance intention: an integrated flow framework", Information and Management, Vol. 53, pp. 279-295.

Gupta, S. and Bostrom, R.P. (2009), "Technology-mediated learning: a comprehensive theoretical model", Journal of the Association for Information Systems, Vol. 10 No. 9, pp. 686-714.

Hair, J.F., Ringle, C.M. and Sarstedt, M. (2011), "PLS-SEM: indeed a silver bullet", Journal of Marketing Theory and Practice, Vol. 19 No. 2, pp. 139-152.

Hair, J.F., Sarstedt, M., Ringle, C.M. and Mena, J.A. (2012), "An assessment of the use of partial least squares structural equation modelling in marketing research", Journal of the Academy of Marketing Science, Vol. 40 No. 3, pp. 414-433.

Hall, A. (2009), "Perceptions of the authenticity of reality programs and their relationships to audience involvement, enjoyment, and perceived learning", Journal of Broadcasting Electronic Media, Vol. 53 No. 4, pp. 515-531.

Harasim, L., Hiltz, S.R., Teles, L. and Turoff, M. (1995), Learning Networks. A Field Guide to Teaching and Learning Online, MIT Press, Cambridge, MA.

Herrington, J., Oliver, T.C. and Reeves, R. (2010), A Guide to Authentic e-Learning, Routledge, New York, NY. 
Hsu, C.-L. and Lin, J.C.-C. (2008), “Acceptance of blog usage: the roles of technology social influence and knowledge sharing motivation", Information and Management, Vol. 45, pp. 65-74.

Huang, Y.-M., Liao, Y.-W., Huang, S.-H. and Chen, H.-C. (2014), "A jigsaw-based cooperative learning approach to improve learning outcomes for mobile situated learning", Educational Technology and Society, Vol. 17 No. 1, pp. 128-140.

Jonassen, D.H. and Land, S.M. (2000), Theoretical Foundations of Learning Environments, Lawrence Erlbaum Associates, Mahwah, NJ.

Kashdan, T.B., Stiksma, M.C., Disabato, D.J., McKinght, P.E., Bekier, J., Kaji, J. and Lazarus, R. (2018), "The five-dimensional curiosity scale: capturing the bandwidth of curiosity and identifying four unique subgroups of curious people", Journal of Research in Personality, Vol. 73, pp. 130-149.

Kennedy, G. and Cuts, Q. (2005), "The association between students use and electronic voting system and their learning outcomes", Journal of Computer Assisted Learning, Vol. 21 No. 4, pp. 260-268.

Kim, D.H., Seely, N.K. and Jung, J.H. (2017), "Do you prefer Pinterest or Instagram? The role of imagesharing SNSs and self-monitoring in enhancing ad effectiveness", Computers in Human Behavior, Vol. 70, pp. 535-543.

Kurthakoti, R., Boostrom, R.E., Summey, J.H. and Campbell, D.A. (2013), "Enhancing classroom effectiveness through social networking tools", Marketing Education Review, Vol. 23 No. 3, pp. 251-264.

Kwak, K.T., Choi, S.K. and Lee, B.G. (2014), "SNS flow, SNS self-disclosure and post hoc interpersonal relations change: focused on Korean Facebook user", Computers in Human Behavior, Vol. 31, pp. 294-304.

Lantz, M.E. (2010), "The use of clickers in the classroom: teaching innovation or merely an amusing novelty?", Computers in Human Behavior, Vol. 26 No. 4, pp. 556-561.

LaSalle, D. and Britton, T.A. (2003), Priceless: turning Ordinary Products into Extraordinary Experiences, Harvard Business School Press, Boston, M.A.

Lee, M.-C. (2010), "Explaining and predicting users' continuance intention toward e-learning: an extension of the expectation-confirmation model", Computers and Education, Vol. 54, pp. 506-516.

Lee, Y., Chen, A. and Ilie, V. (2012), "Can online wait be managed? the effect of filler interfaces and presentation modes on perceived waiting time online", MIS Quarterly, Vol. 36 No. 2, pp. 365-394.

Lemon, K. and Verhoef, P. (2016), "Understanding customer experience throughout the customer journey", Journal of Marketing, Vol. 80 No. 6, pp. 69-96.

Leong, P. (2011), "Role of social presence and cognitive absorption in online learning", Distance Education, Vol. 32 No. 1, pp. 5-28.

Liao, Y.W., Huang, Y.-M., Chen, H.-C. and Huang, S.-H. (2015), "Exploring the antecedents of collaborative learning performance over social networking sites in ubiquitous learning contexts", Computers in Human Behavior, Vol. 43, pp. 313-323.

Lin, H.F. (2009), "Examining of cognitive absorption influencing the intention to use a virtual community", Behavior and Information Technology, Vol. 28 No. 5, pp. 421-431.

Lin, A.C.H., Fernandez, W.D. and Gregor, S. (2012), "Understanding web enjoyment experiences and informal learning: a study in a museum context", Decision Support Systems, Vol. 53 No. 4, pp. 846-858.

Lin, A.C.H. and Gregor, S. (2006), "Designing websites for learning and enjoyment: a study of museum experiences", International Review of Research in Open Distance Learning, Vol. 7, pp. 1-21.

Liu, G.Z. (2008), "Innovating research topics in learning technology: where are the new blue oceans?", British Journal of Educational Technology, Vol. 39 No. 4, pp. 738-747.

Liu, S., Liao, H. and Pratt, J.A. (2009), "Impact of media richness and flow on e-learning technology acceptance", Computers and Education, Vol. 52 No. 3, pp. 599-607. 
Lobler, M.L., Visentini, M.S. and Estivalete, B. (2011), "A vision of Orkut's users: studying this phenomenon through cognitive absorption", Jistem Journal of Information Systems and Technology Management, Vol. 8 No. 1, pp. 51-72.

MacGeorge, E., Homan, S.R., Dunning, J.B., Elmore, D., Bodie, G.D., Evans, B.E. and Khichadia, S. (2008), "The influence of learning characteristics on evaluation of audience response technology", Journal of Computing in Higher Education, Vol. 19 No. 2, pp. 25-46.

McCorkle, D.E. and McCorkle, Y.L. (2012), "Using Linkedin in the marketing classroom: exploratory insights and recommendations for teaching social media/networking", Marketing Education Review, Vol. 22 No. 2, pp. 157-166.

Marketing Science Institute (MSI) (2016), “2016-2018 Research priorities”, available at: www.msi.org/ research/(2016)-2018-research-priorities/ (accessed 23 October 2018).

Martinez, M. (2003), "High attrition rate in e-learning: challenging, predictors, and solutions", The eLearning Developers Journal, July, pp. 1-7.

Milosevic, I., Zivkovic, D., Arsic, S. and Manasijevic, D. (2015), "Facebook as virtual classroom-social networking in learning and teaching among Serbian students", Telematics and Informatics, Vol. 32 No. 4, pp. 576-585.

Miranda, S.M. and Saunders, C.S. (2003), "The social construction of meaning: an alternative perspective on information sharing", Information Systems Research, Vol. 14 No. 1, pp. 87-106.

Moon, J.W. and Kim, Y.G. (2001), "Extending the TAM for a world-wide-web context", Information and Management, Vol. 38 No. 4, pp. 217-230.

Northey, G., Bucic, T., Chylinski, M. and Govind, R. (2015), "Increasing student engagement using asynchronous learning", Journal of Marketing Education, Vol. 37 No. 3, pp. 171-180.

Omnicore (2019), "Pinterest by the numbers: Stats, demographics and fun facts", available at: www. omnicoreagency.com/pinterest-statistics/ (accessed 9 March 2019).

Ottoni, R., Pesce, J.P., Las Casas, D., Franciscani, G., Jr, Meira, W., Jr, Kumaraguru, P. and Almeida, V. (2013), "Ladies first: analyzing gender roles and behaviors in pinterest", Proceedings of ICWSM, available at: http://homepages.dcc.ufmg.br/ rapha/papers/ladiesfirstICWSM13.pdf (accessed 23 October 2018).

Pallud, J. (2017), "Impact of interactive technologies on stimulating learning experiences in a museum", Information and Management, Vol. 54 No. 4, pp. 465-478.

Panitz, T. (1996), "A definition of collaborative versus cooperative learning", deliberations", available at: www.londonmet.ac.uk/deliberations/collaborative-learning/panitz-paper.cfm (accessed 23 October 2018).

Papagiannidis, S., Pantana, E., See-To, E.W.-K., Dennis, C. and Bourlakis, M. (2017), "To immerse or not? Experimenting with two virtual retail environments", Information Technology and People, Vol. 30 No. 1, pp. 163-188.

Park, J., Parsons, D. and Ryu, H. (2010), “To flow and not to freeze: applying flow experience to mobile learning", IEEE Transactions on Learning Technologies, Vol. 3 No. 1, pp. 56-67.

Pavlou, P.A. and El Sawy, O.A. (2006), "From IT leveraging competence to competitive advantange in turbulent environments: the case of new product development", Information Systems Research, Vol. 17 No. 3, pp. 198-227.

Pekrun, R. (2006), "The control-value theory of achievement emotions: assumptions, corollaries, and implications for educational research and practice”, Educational Psychology Review, Vol. 18 No. 4, pp. 315-341.

Pelet, J.E., Ettis, S. and Cowart, K. (2017), "Optimal experience of low enhanced by telepresence: evidence from social media use", Information and Management, Vol. 54, pp. 115-128.

Peruta, A. and Shields, A.B. (2017), "Social media in higher education: understanding how colleges and universities use Facebook", Journal of Marketing for Higher Education, Vol. 27 No. 1, pp. 131-143. 
Peter, S., Straub, D. and Rai, A. (2007), "Specifying formative constructs in information systems research”, MIS Quarterly, Vol. 31 No. 4, pp. 623-656.

Prince, M. (2004), "Does active learning work? A review of the research", Journal of Engineering Education, Vol. 93 No. 3, pp. 223-233.

Reychav, I., Dunaway, M. and Kobayashi, M. (2015), "Understanding mobile technology-fit behaviours outside the classroom", Computers and Education, Vol. 87, pp. 142-150.

Reychav, I. and Wu, D. (2015a), "Are your users actively involved? A cognitive absorption perspective in mobile training”, Computers in Human Behavior, Vol. 44, pp. 335-346.

Reychav, I. and Wu, D. (2015b), "Mobile collaborative learning. The role of individual learning in groups through text and video content delivery in tablets", Computers in Human Behavior, Vol. 50, pp. 520-534.

Rodríguez-Ardura, I. and Meseguer-Artola, A. (2016), "E-learning continuance the impact of interactivity and the mediating role of imagery, presence and flow", Information and Management, Vol. 53, pp. 504-516.

Rouibah, K. (2008), "Social usage of instant messaging by individuals outside the workplace in Kuwait", Information Technology and People", Vol. 21 No. 1, pp. 34-68.

Ruthig, J.C., Perry, R.P., Hladkyj, S., Hall, N.C., Pekrun, R. and Chipperfield, J.G. (2008), "Perceived control and emotions: interactive effects on performance in achievement settings", Social Psychology of Education, Vol.11 No. 2, pp. 161-180.

Ryu, H. and Parsons, D. (2012), "Risky business or sharing the load? Social flow in collaborative mobile learning", Computers and Education, Vol. 58 No. 2, pp. 707-720.

Saadé, R. and Bahli, (2005), “The impact of cognitive absorption on perceived usefulness and perceived ease of use in on-line learning: an extension of the technology acceptance model", Information and Management, Vol. 42, pp.317-327.

Sharma, S.K., Joshi, A. and Sharma, H. (2016), "A multi-analytical approach to predict the Facebook usage in higher education", Computers in Human Behavior, Vol. 55, pp. 340-353.

Shaw, C. and Ivens, J. (2005), Building Great Customer Experiences, Palgrave Macmillan, New York, NY, ISBN 1-403-93949-7.

Skadberg, Y.X. and Kimmel, J.R. (2004), "Visitors' flow experience while browsing a web site: its measurement, contributing factors and consequences", Computers in Human Behavior, Vol. 20 No. 3, pp. 403-422.

Stone, M. (1974), "Cross-validatory choice and assessment of statistical predictions", Journal of the Royal Statistical Society. Series B (Methodological), Vol. 36 No. 2, pp. 111-147.

Stowell, J.R. and Nelson, J.M. (2007), "Benefits of electronic audience response systems on student participation, learning and emotion”, Teaching of Psychology, Vol. 34 No. 4, pp. 253-258.

Sung, H.-Y. and Hwang, G.-Y. (2013), "A collaborative game-based learning approach to improving student's learning performance in science courses”, Computers and Education, Vol. 63, pp. 43-51.

Tan, W.-H., Lee, P.-W. and Hsu, C.-W. (2015), "Investigation of temporal dissociation and focused immersion as moderators of satisfaction-continuance intention relationship: smartphone as an example", Telematics and Informatics, Vol. 32 No. 4, pp. 745-754.

Tellegen, A. and Atkinson, G. (1974), "Openness to absorbing and self-altering experiences ("absorption") a trait related to hypnotic susceptibility", Journal of Abnormal Psychology, Vol. 83 No. 3, pp. 268-277.

Tenenhaus, M., Vinzi, V.E., Chatelin, Y.-M. and Lauro, C. (2005), "PLS path modelling”, Computational Statistics and Data Analysis, Vol. 48, pp. 159-205.

Tharenou, P. (2001), "The relationship of training motivation to participation in training and development", Journal of Occupational and Organizational Psychology, Vol. 74 No. 5, pp. 599-621. 
Urbach, N. and Ahlemann, F. (2010), "Structural equation modeling in information systems research using partial least squares", Journal of Information Technology Theory and Application, Vol. 11 No. 2, pp. 5-40.

van der Heijden, H. (2004), "User acceptance of hedonic information systems", MIS Quarterly, Vol. 28 No. 4, pp. 695-704.

Wakefield, R. and Whitten, D. (2006), "Mobile computing: a user study of hedonic/utilitarian mobile device usage", European Journal of Information Systems, Vol. 15 No. 3, pp. 292-300.

Wang, X., Yu, C. and Wei, Y. (2012), "Social media peer communication and impacts on purchase intentions: a consumer socialization framework", Journal of Interactive Marketing, Vol. 26 No. 4, pp. 198-208.

Webster, J. and Hackley, P. (1997), "Teaching effectiveness in technology-mediated distance learning”, Academy of Management Journal, Vol. 40 No. 6, pp. 1282-1309.

Webster, J. and Ho, H. (1997), “Audience engagement in multimedia presentations", ACM SIGMIS Database, Vol. 28 No. 2, pp. 63-77.

Weniger, S. and Loebbecke, C. (2011), "Researching cognitive absorption in the context of fun-oriented information systems usage: an exploratory study", ECIS 2011 Proceedings, p. 135.

Wu, J.W. and Wang, H.-S.L. (2011), "An empirical study of flow experiences in social network sites", Pacific Asia Conference on Information Systems, PACIS, Brisbane, Queensland, Australia, pp. 7-11.

Yoo, Y., Kanawattachachai, P. and Citurs, A. (2002), "Forging into the wired wilderness: a case study of a technology-mediated distributed discussion-based class", Journal of Management Education, Vol. 26 No. 2, pp. 139-163.

Zhang, J. and Daugherty, T. (2009), "Third-person effect and social networking: implications for online marketing and word-of-mouth communication”, American Journal of Business, Vol. 24 No. 2, pp. 53-64.

Zhou, T., Li, H. and Liu, Y. (2010), "The effect of flow experience on mobile SNS users' loyalty", Industrial Management and Data Systems, Vol. 110 No. 6, pp. 930-946.

\section{Further reading}

Tuten, T. and Marks, M. (2012), "The adoption of social media as educational technology among marketing educators", Marketing Education Review, Vol. 22 No. 3, pp. 201-214.

\section{Corresponding author}

Miguel Guinaliu-Blasco can be contacted at: guinaliu@unizar.es

For instructions on how to order reprints of this article, please visit our website: 